\title{
VALUATION OF PUBLIC GOODS AND ECOSYSTEM SERVICES PROVIDED BY AGRICULTURE
}

\author{
Ligita Melece, Ilze Shena \\ Institute of Agricultural Resources and Economics, Latvia \\ ligita.melece@arei.lv
}

\begin{abstract}
The public good ecosystem services, particularly ecosystem services provided by agriculture, are defined as goods and services often delivered as side-effects of farmers' production contribute to human well-being. The aim of the study is twofold: 1) to ascertain the concepts and options for ecosystem services, particularly, agro-ecosystem services, valuation; and 2) to assess the supporting activities, based on implementation effectiveness analysis of Rural Development Program's (RDP) 2007-2013 agri-environmental measures in Latvia. The principal materials used for the studies are as follows: different sources of literature, e.g. scholars' articles, research papers and the reports of institutions, inter alia, European Union; the data from Eurostat database, Central Statistical Bureau database and unpublished data from database of Latvian Rural Support Service. For investigation of impact of agricultural landscape sustainability aspects the following data were used: payment agri-environment measures'; and commitment area of agricultural land or area, as well as the structure of crop areas. The data that have been used reflect implementation of agri-environment measures under RDP 2007-2013. The suitable qualitative and quantitative research methods for certain tasks have been used in the process of study. The findings show that the expected positive effect of implementation of agri-environmental measures of RDP 2007-2013 in Latvia on the sustainability and resilience of agricultural landscapes, as a provider of main ecosystem services, as well as conservation of agricultural biodiversity has not been received. Besides, in order to investigate the further effectiveness of state support for ecosystem services, the assessment of planned agri-environmental measures of new RDP 2014-2020 is performed.
\end{abstract}

Keywords: ecosystem services, valuation, agro-ecosystem, agriculture.

\section{Introduction}

Although there is no consensus among scholars to define the ecosystem services, there is a worldwide acceptance that the ecosystem functions, which can be turned into services, contribute benefits to the human well-being, including survival and quality of life [1-2]. They include provisioning, regulating, and cultural services that directly affect people, and the supporting services, which necessary to maintain other services [3].

Ecosystem services could directly or indirectly contribute to human well-being and sustain livelihoods through appropriated ecosystem structures, functions or processes [4-5]. Besides, the relationship between ecosystem services and human well-being is complex and multidimensional. The services, particularly agro-ecosystem services, are provided by interaction between humans and nature. Therefore, they have an intrinsic social-ecological character [4-6], and are social, cultural, economic and environmental interlinked [7-8]. These agro-ecosystem services mainly are deeply interlinked (e.g., primary production, soil quality, nutrient cycling, and water cycling) and involve various aspects of the same biological processes.

Ecosystem services provide the public goods and services. The economic theory concept defines public goods with following characteristics: non-excludable - if the good is available to one person, others cannot be excluded from the benefits it confers and non-rival - if the good is consumed by one person it does not reduce the amount available to others [9].

The relationship between biodiversity and ecosystem service supply could best be maintained within and among landscapes [2; 4-5; 10], particularly agricultural landscapes, sometimes named as traditional landscapes. Some sources indicate agricultural landscapes as cultural landscapes, which are increasingly threatened by both intensification and abandonment [11].

Intensification was one aspect of the modernisation of agriculture, but it had the unforeseen side effect of increasing pressure on the environment [1]. Recently biodiversity in Central and Eastern European farmlands has also started to decrease sharply, due to rapid economic transformations that are changing the region's agricultural landscape [12]. Several instruments and tools have been developed and made available to farmers to mitigate the environmental impact of agriculture under the EU Common Agricultural Policy (CAP).

The public support, established by CAP and provided by Rural Development Programme (RDP), is now increasingly oriented towards the provision of environmental and other public goods and 
services. Agri-environment payments received by the farmers that implement agri-environment measures have been one of policy tools [13]. Agri-environment measures are developed under the each Member State's RDP, which are mandatory for national or regional governance, but voluntary for the farmers.

Therefore, the aim of the study is twofold: 1) to ascertain the concepts and options for ecosystem services, particularly, agro-ecosystem services, valuation; and 2) to assess the supporting activities, based on implementation effectiveness analysis of RDP 2007-2013 agri-environmental measures in Latvia. In particular, the capability to provide sustainable basis for agro-ecosystem functions biodiversity and agricultural or cultural landscapes as backbone of multifunctional activities in the rural areas.

\section{Materials and methods}

The principal materials used for the studies are as follows: different sources of literature, e.g. scholars' articles, research papers and the reports of institutions. The data were obtained from: Eurostat online database [14], online database of Central Statistical Bureau (CSB) Latvia [15], and unpublished data from database of Latvian Rural Support Service. For investigation of agricultural landscape sustainability aspects the following data were used: payment area under agri-environmental measures as well as the amount of support paid for agricultural land or utilized agricultural area (hereinafter - UAA), as well as the structure of crop areas and the farming type. The data that have been used reflect performance or impact of agri-environment measures implementation under RDP 2007-2013.

For evaluation and comparison the state and trends of agro-ecosystem management among EU countries, the data of the EU Member States and eight EU countries of Baltic Sea Region: Denmark, Estonia, Finland, Germany, Latvia, Lithuania, Poland and Sweden, as well as the Baltic States were evaluated. The Baltic Sea Region countries, which are the Member States of EU, further, are indicated as Baltic Sea countries.

The suitable qualitative and quantitative research methods for certain tasks have been used in the process of study: monographic; analysis and synthesis; logical and abstractive constructional; spatial analysis of field blocks, using GIS (Geographic Information System); etc. Due to limited space, only the most important results of research are set out in the paper.

\section{Results and discussion}

In general it can be concluded that agriculture nowadays faced with contradictory groups of requirements that could be fulfilled to provide a number of ecosystem services. First group contains so called provisioning ecosystem services are aimed to supply a wide range of agricultural products as goods (e.g., food, various biomass materials for manufacturing, timber etc.). This consequently requires intensifying production effectively, for example, to increase application of inorganic fertilizers, to replace less productive traditional breeds, scale enlargement etc. A second group contains new services of ecosystem services, which should be provided by farmers, such as so called regulating services (e.g., flood prevention, soil erosion prevention, emission decreasing etc.), and various activities to preserve nature and ecosystems' functional capacities, especially biodiversity. Besides, the preservation of both types - wild biodiversity and agro-biodiversity are important to ensure landscapes as main of ecosystem services. Cultural ecosystem services are defined as "...nonmaterial benefits people obtain from ecosystems through spiritual enrichment, cognitive development, reflection, recreation, and aesthetic experiences" [3 p. 4]. They comprise six main subsets: 1) cultural identity - focusing on the cultural linkage between humans and their environment, and connected to knowledge systems and language; 2) heritage values - encompassing memories related historically valuable land use practices; 3) spiritual services - sacred, religious or other forms of spiritual inspiration derived from ecosystems; 4) inspiration - which might be expressed through the artifacts, arts or folklore; 5) aesthetic appreciation of landscapes; and 6) recreation and tourism [16].

\section{Valuation issues of ecosystem services}

Several causes, which create problems in reconciling different methods of ecosystem services valuation, were identified by scholars; inter alia, lack of methods, including for linking non-monetary 
and monetary valuation [17]. Withal, most of values are outside the market and best considered as non-tradable public benefits [16]. As noted above, agricultural (cultural) landscapes provide important ecosystem services, be shelter for agricultural land biodiversity, and are devoted to heritage [11]. As examples the main indicators, characteristics and data for agricultural landscapes' valuation are indicated in Table 1.

Table 1

The indicators its groups and characteristics for agricultural landscapes' valuation

\begin{tabular}{|c|c|c|c|}
\hline Group & Indicator & Characteristics & Data \\
\hline \multirow{3}{*}{$\begin{array}{l}\text { Management } \\
\text { intensity }\end{array}$} & Economic farm size & $\begin{array}{l}\text { Distinguish between capital-intensive, } \\
\text { large-scale farms and small-scale farms }\end{array}$ & ESU* \\
\hline & Nitrogen $(\mathrm{N})$ input & $0-50 ; 50-150 ;$ and $>150 \mathrm{~N} \mathrm{~kg} \cdot \mathrm{ha}^{-1}$ & $\mathrm{~N} \mathrm{~kg} \cdot(\text { ha } \cdot \text { year })^{-1}$ \\
\hline & $\begin{array}{l}\text { Energy Content } \\
\text { Output (ECO) }\end{array}$ & ECO as a score between 0 and 1 & $\mathrm{MJ} \cdot(\text { ha } \cdot \text { year })^{-1}$ \\
\hline \multirow[b]{2}{*}{$\begin{array}{l}\text { Landscape } \\
\text { structure }\end{array}$} & Field Size & $<0.5$ ha, $0.5-1$ ha, $1-10$ ha and $>10$ ha & ha \\
\hline & $\begin{array}{l}\text { Green linear elements } \\
\text { (GLE) }\end{array}$ & $\begin{array}{l}\text { High values landscapes with small } \\
\text { fields and/or GLE (e.g., tree lines, } \\
\text { hedges) }\end{array}$ & $\begin{array}{l}\text { No of GLE per } \\
250 \mathrm{~m} \text { transect }\end{array}$ \\
\hline \multirow{2}{*}{$\begin{array}{l}\text { Value and } \\
\text { meaning }\end{array}$} & $\begin{array}{l}\text { Product Designated } \\
\text { Origin (PDO) }\end{array}$ & $\begin{array}{l}5 \mathrm{~km} \text { buffer around defined PDO } \\
\text { production area }\end{array}$ & No of PDOs \\
\hline & $\begin{array}{l}\text { Google Earth/Google } \\
\text { Maps photo }\end{array}$ & $\begin{array}{l}\text { Users added geotagged landscape } \\
\text { photos to Google Earth/Google Maps }\end{array}$ & $\begin{array}{l}\text { No of } \\
\text { photos } \cdot \mathrm{km}^{-2}\end{array}$ \\
\hline
\end{tabular}

* ESU - European size unit - standard gross margin EUR 1200

Eastern Europe countries, including Latvia, are characterized by a low score on the landscape structural and value and meaning dimension, but high on management intensity score [11].

Some scholars are aware that very important notions such as sense of place, history, or inspiration are not included in the indicators [11]. Besides, the implementation of valuation models is scare, because variability in species responses to specific landscape constituents, which act positively for some species and negatively for others [18].

In total 28 agri-environmental indicators are accepted to monitor the implementation of environmental measures under CAP [19]. These indicators aim to: provide information on the farmed environment; track the impact of agriculture on the environment; assess the impact of agricultural and environmental policies on environmental management of farms; inform agricultural and environmental policy decisions; illustrate agri-environmental relationships to the broader public [19].

Notwithstanding, the data indicates that there is lack data for several agri-environmental indicators: "17 Pesticide risk", " 22 Genetic diversity" and " 23 High Nature Value farmland". Besides, the data of indicators: "14 Risk of land abandonment", "20 Water abstraction", "26 Soil quality" and "27.1 Water quality - Nitrate pollution", are not actualized and the latest data is from 2009 or older (2005). Indicator " 23 High nature value farmland" is proposed as one of the impact indicators to be included in the CAP monitoring and evaluation framework for RDP 2014-2020 [19].

Moreover, due to the lack of robust and quantitative analysis of the linkages between policy drivers and environmental outcomes in the agriculture, it is argued that the performance of agri-environment schemes is difficult to measure [20].

\section{Implementation of CAP, RDP and agri-environmental measures}

For ensuring the biodiversity EU Biodiversity Action Plan for Agriculture was developed and following main priorities have been integrated in the RDP: the promotion and support of environmentally-friendly farming practices, systems that benefit biodiversity directly or indirectly; the maintenance and enhancement of good ecological infrastructures. Agri-environment measures are designed to encourage farmers to protect and enhance the environment on their farmland and to provide payments as compensation to farmers. For 2020 the target share of area in the total UAA, in which agri-environmental measures were implemented, is approved on EU level. In 2013 Latvia was in the fifth latest place among the EU countries with the share $12.5 \%$ of UAA under agri- 
environmental payments [19]. Latvia is among other countries with the lowest target, but shows the worst results (Fig. 1).

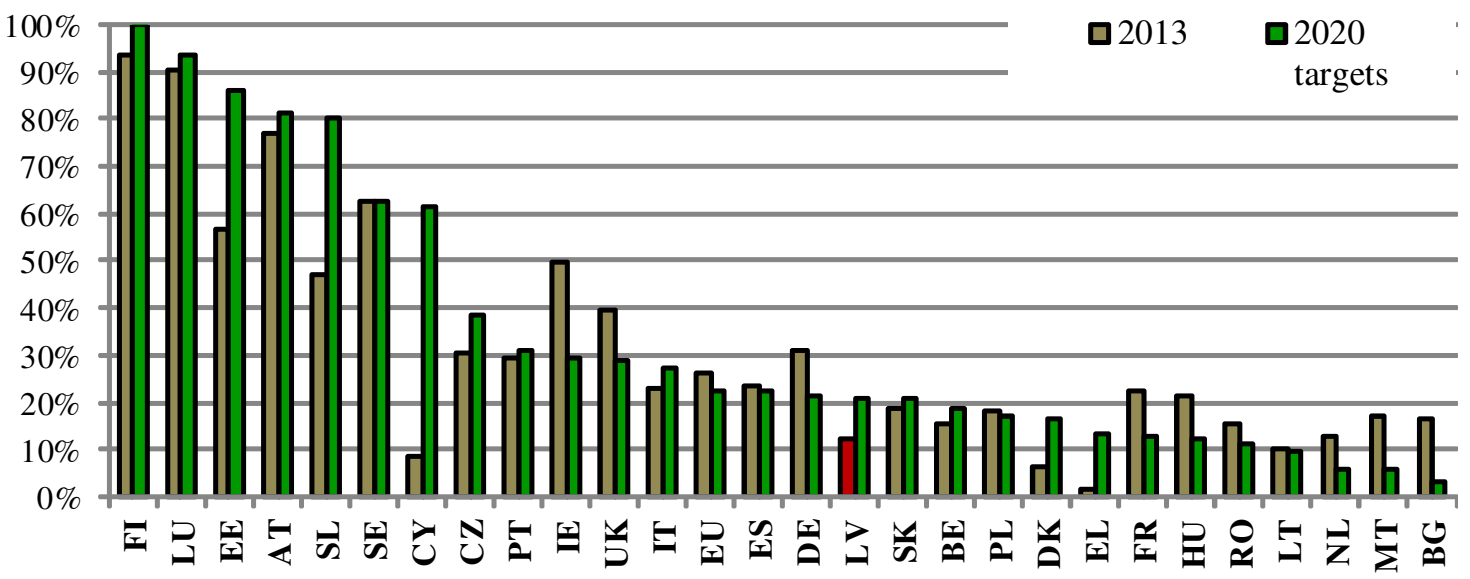

Fig. 1. The share of area under agri-environmental commitments on total UAA of EU countries and EU average in 2013 and target in 2020

The potential beneficiaries of agri-environment measures of RDP 2007-2013 (Axis 2) were indicated by Ministry of Agriculture. While eligibility conditions were chosen in general, and relatively few were aimed for specific areas or activities [21]. As a result of such approach the share of agri-environment measures' areas are not implemented in the areas with higher importance of landscape resilience - the Nature 2000 areas; as well as nitrate vulnerable zones (Fig. 2).

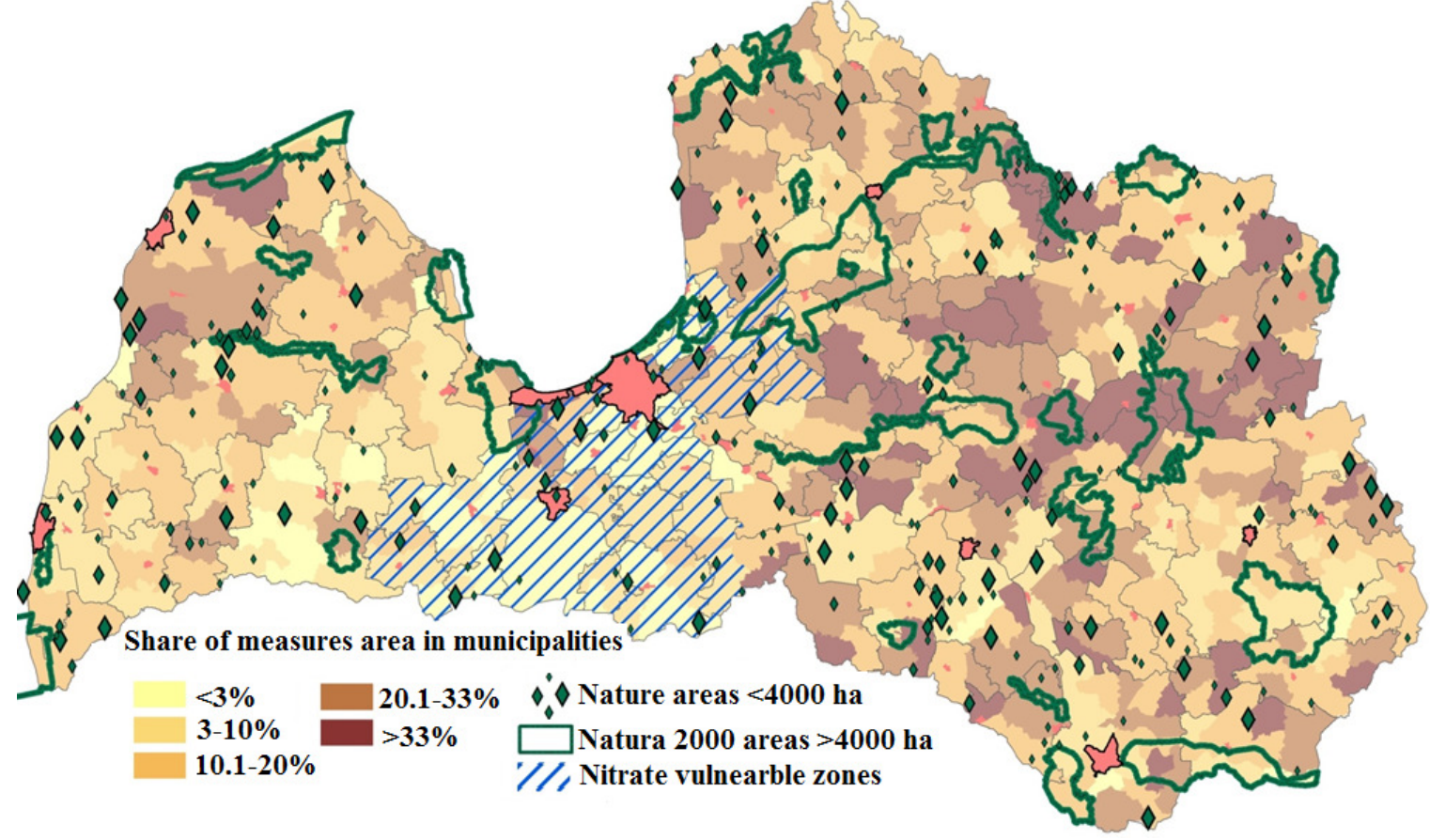

Fig. 2. Share (\%) of area under implemented agri-environmental measures in Latvia's municipalities, and most important environmental target territories, 2013

As can see (Fig. 3), the share of UAA under Natura 2000 is not a highest among EU countries.

From 2015 onwards, the regulations of EU require that the ratio of permanent grassland compared to the total agricultural area claimed must not decrease by more than five per cent. Latvia yet not takes strong measures and actions to increase the area of permanent grassland, particularly in the areas with intensive cropping activities. 
In Latvia 40-80 \% of the EU important grassland habitats in Natura 2000 areas were not managed properly [21]. Moreover, the spatial analysis of UUA changes in the period 2007-2012 shows large decrease of permanent grasslands.

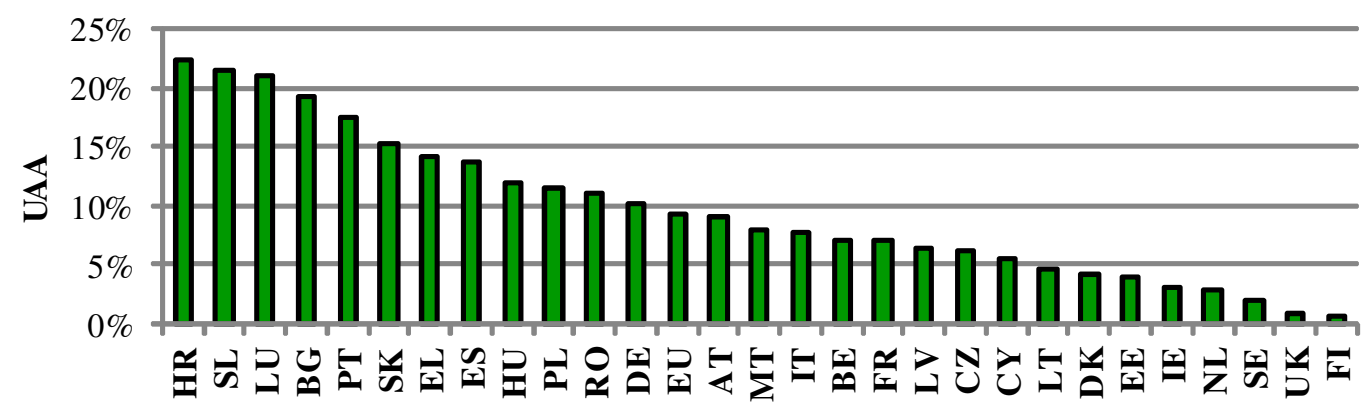

Fig. 3. The share of UAA under Natura 2000 in EU countries and EU average, 2016

The negative trend is observed as the area of permanent grassland and other cultures without wheat and rape has decreased statistically significant (Fig. 4), which suggests both decline in agro biodiversity and nature biodiversity, as well as decrease the quality (attractiveness) of landscapes.

The potential benefits of increasing agricultural land use diversity is not limited to increasing economic resilience of landscapes, but also provide co-benefits for other important functions of agricultural landscapes. Moreover, the provision of cultural ecosystem services is greater in diverse agricultural landscapes [10].

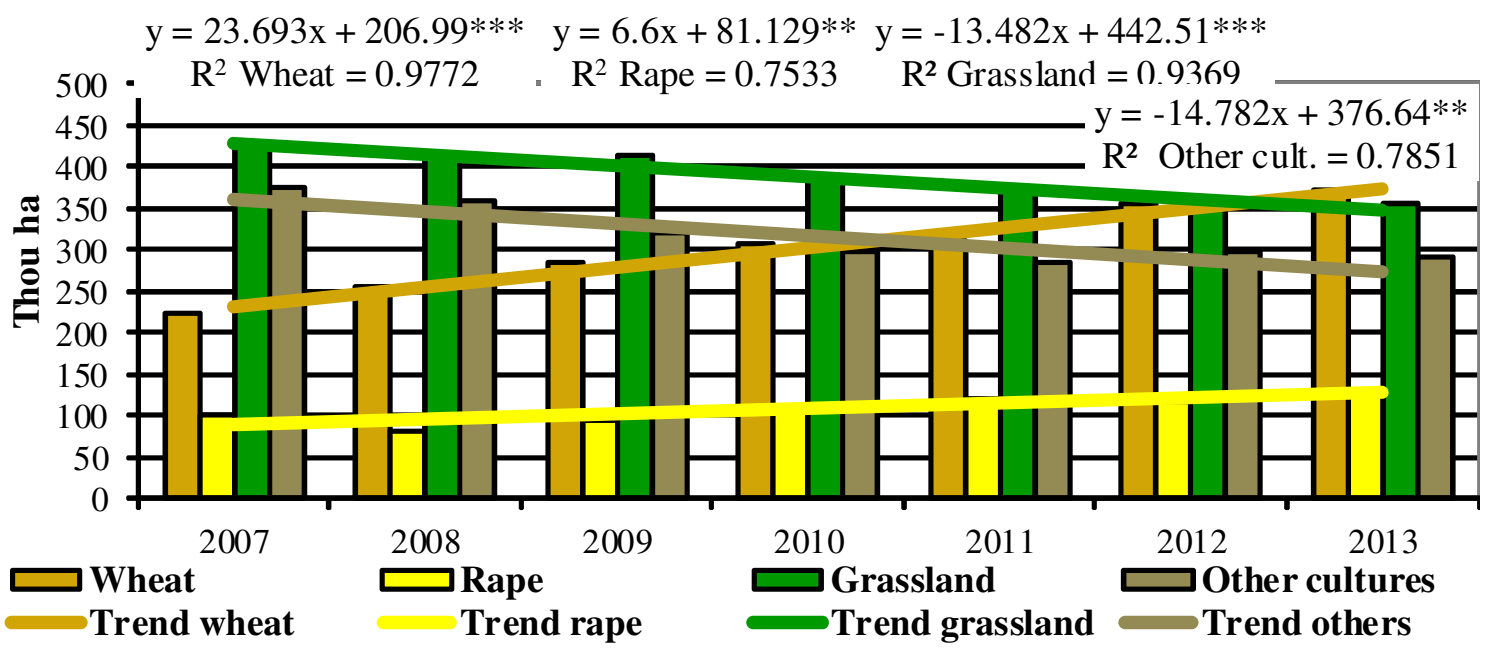

Fig. 4. The area trend of wheat, rape, permanent grassland and other cultures, 2007-2013

The maintenance of permanent cultures, pastures and grasslands support several ecosystem functions and services, including green-house gas emissions and fertilisers pollution. The tendency of permanent crop and permanent grassland proportion in total UAA from 2005 to 2013 not show the improvements, but decreasing of permanent crops (Fig. 5).

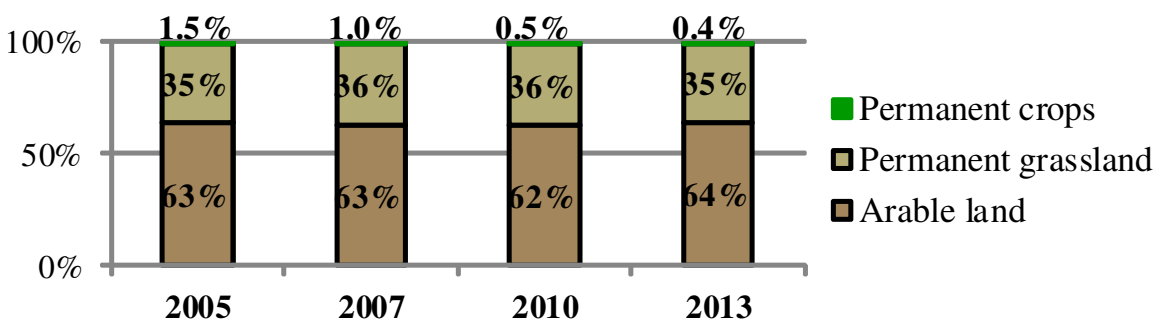

Fig. 5. The share of permanent crops and grasslands, and arable land in Latvia, 2005-2013

Further fulfilment of EU requirements to maintain permanent grassland proportion is threatened. The results of study [22] indicated that the potential support, which could be granted as payments for 
farmers, is lower in the Baltic States, comparing among Baltic Sea countries and EU average, and the lowest in Latvia among the Baltic States (Table 2).

Table 2

Estimated cost to maintain permanent grassland by Baltic Sea countries and EU average

\begin{tabular}{|l|c|c|c|c|}
\hline \multirow{2}{*}{ Country } & \multirow{2}{*}{ PEA* average, ha } & \multirow{2}{*}{ PP** in PEA, \% } & \multicolumn{2}{|c|}{ Costs $^{*}$} \\
\cline { 4 - 5 } & & & EUR ha $^{-1}$ PP & EUR ha $^{-1}$ PEA \\
\hline Denmark & 80.7 & $5 \%$ & 124 & 3 \\
\hline Germany & 84.3 & $24 \%$ & 251 & 37 \\
\hline Estonia & $\mathbf{1 2 3 . 5}$ & $\mathbf{2 0} \%$ & $\mathbf{5 6}$ & $\mathbf{3}$ \\
\hline Latvia & $\mathbf{6 1 . 3}$ & $\mathbf{2 7} \%$ & $\mathbf{4}$ & $\mathbf{0}$ \\
\hline Lithuania & $\mathbf{5 1 . 4}$ & $\mathbf{1 2} \%$ & $\mathbf{1 5}$ & $\mathbf{1}$ \\
\hline Poland & 17.3 & $17 \%$ & 176 & 20 \\
\hline Finland & 51.6 & $2 \%$ & 173 & 1 \\
\hline Sweden & 96.6 & $15 \%$ & 274 & 17 \\
\hline EU-27 & 31.2 & $25 \%$ & 216 & 17 \\
\hline
\end{tabular}

* PEA - potential eligible area; ** PP - permanent pasture

Numerous studies indicated the problem and argued that the stain between owners (i.e. land owners) property rights and the responsibilities towards the whole community and society has been seen as a major weakness in payments to ecosystem services [18; 23]. Moreover, some authors consider that as long as the payments have legal imperfections; and are not to guarantee an effective protection to ecosystem services, they could not been implemented [23].

The reduction of crop species and varieties causes decreasing of biodiversity, because more diverse land cover, inter alia, diversification in crop type, creates a greater number of habitats for species from different taxa.

The changes regarding to the biodiversity agricultural crops are summarized in the Table 3 , and show growing tendency to commercial monocultures expansion. Its demonstrate that raising of areas of rape and wheat probably has occurred due to reducing cultivation of other agricultural crops.

The changes of various crops share (\%) in total UAA from 2005 to 2016

Table 3

\begin{tabular}{|l|c|c|c|c|}
\hline \multicolumn{1}{|c|}{ Crop type } & $\mathbf{2 0 0 5}$ & $\mathbf{2 0 1 6}$ & \multicolumn{2}{c|}{ Changes 2016/2005, \% } \\
\hline Winter wheat & 132.0 & 329.9 & $149.9 \%$ & $\uparrow$ \\
\hline Rye & 39.3 & 36.3 & $-7.6 \%$ & \\
\hline Winter barley & 2.8 & 2.0 & $-28.6 \%$ & \\
\hline Winter triticale & 13.3 & 9.3 & $-30.1 \%$ & \\
\hline Wheat & 55.4 & 153.0 & $176.2 \%$ & \\
\hline Barley & 145.9 & 94.1 & $-35.5 \%$ & \\
\hline Oat & 58.0 & 64.6 & $11.4 \%$ & $\uparrow$ \\
\hline Buckwheat & 10.4 & 17.9 & $72.1 \%$ & $\uparrow$ \\
\hline
\end{tabular}

Analysing the cereals proportion in the crop rotation, the four-year period was chosen and average of cereals presence in this period was evaluated. The results show that there is relatively high proportion of cereals in the structure of crops in territories of high value or protected agricultural landscapes that are threaded the resilience of them (Fig. 6).

It could be noted that the proportion of cereals in three protected landscapes is higher $(23 \%)$ than in all territory of Latvia (19\%) [21].

On EU level it is recognized that under RDP 2014-2020 the crop diversification measure could be targeted to those farms that cultivate one crop - monoculture [24]. The analysis shows that the area reallocation would predominantly take place in wheat, barley and maize over the medium term.

The greening measures of RDP 2014-2020 would impact farms in different ways: increasing costs and thus negatively impacting on income, or creating a direct or a potential loss of income (an 
opportunity cost) as a consequence of compliance with the measures [25]. Moreover, the greening measures, notably the crop diversification and the set-aside, could impact the prices of agricultural products and inputs, and therefore income, where the most affected are farms with a large economic size, followed by small farms [25].

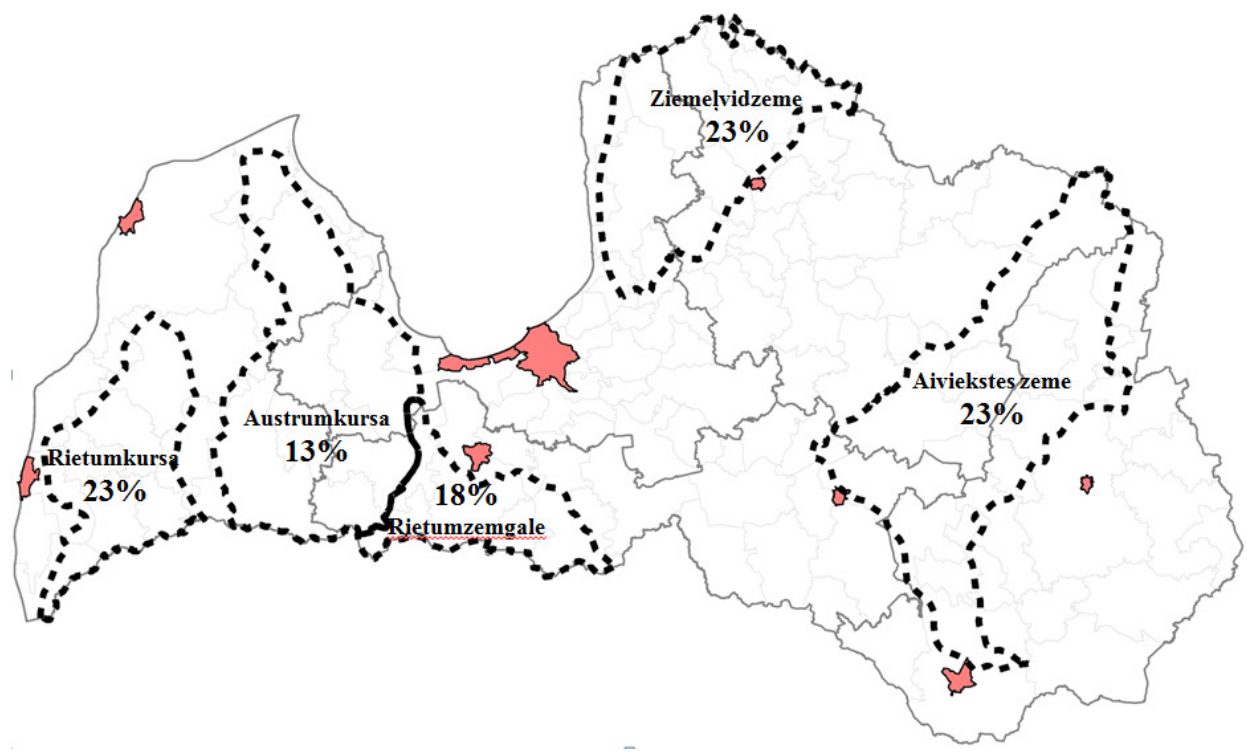

Fig. 6. Proportion of cereals' area in Latvia's protected landscape areas, average of 2013-2016

\section{Conclusions}

1. Ecosystem services, particularly agricultural ecosystem services, including cultural (agricultural) landscapes, have the direct and indirect contributions to human well-being, including survival and quality of life, and accordingly constitute the bases for sustainable rural development.

2. The spatial analysis of implemented agri-environmental measures of Rural Development Program 2007-2013 in Latvia shows that the expected positive effect on the sustainability and resilience of agricultural landscape as a provider of ecosystem services, as well as conservation of both agricultural biodiversity and nature biodiversity have not been received.

3. There are two contradictory groups of requirements that could be fulfilled by agriculture and farming to provide a number of ecosystem services. First group contains so called provisioning ecosystem services and requires intensifying and raising the food and biomass production. But the second group contains new services of ecosystem services so called regulating services and various activities to preserve nature and ecosystems' functional capacities, especially biodiversity.

\section{Acknowledgements}

This research was supported by the National Research Program „Innovation and Sustainable Development" (SUSTINNO).

\section{References}

[1] Bouwma I., Schleyer C., Primmer E., Winkler K. J., Berry P. et al. Adoption of the ecosystem services concept in EU policies. Ecosystem Services, vol. 29, Part B, 2018, pp. 213-222.

[2] Andersen E. The farming system component of European agricultural landscapes, European Journal of Agronomy, vol. 82 (B), 2017, pp. 282-291.

[3] Millennium Ecosystem Assessment (MEA). Ecosystems and Human Well-being: Synthesis. Island Press, Washington, DC, 2005. 155 p.

[4] Bennett E. M., Cramer W., Begossi A., Cundill G., Diaz S. et al., Linking biodiversity, ecosystem services, and human well-being: three challenges for designing research for sustainability. Current Opinion in Environmental Sustainability, vol. 14, 2015, pp. 76-85. 
[5] Maes J., Liquete C., Teller A., Erhard M., Paracchini M.L., Barredo J.I. et al. An indicator framework for assessing ecosystem services in support of the EU Biodiversity Strategy to 2020, Ecosystem Services, vol. 17, 2016, pp. 14-23.

[6] Tancoigne E., Barbier M., Cointet J. P., Richard G., The place of agricultural sciences in the literature on ecosystem services, Ecosystem Services, vol. 10, 2014, pp. 35-48.

[7] Daniel T.C., Muhar A., Arnberger A., Aznar O., Boyd J. W. et al., Contributions of cultural services to the ecosystem services agenda, Proceedings of the National Academy of Sciences, vol. 109(23), 2012, pp. 8812-8819.

[8] Duru M., Therond O., Martin G., Martin-Clouaire R., Magne M. A. et al., How to implement biodiversity-based agriculture to enhance ecosystem services: a review, Agronomy for sustainable development, vol. 35(4), 2015, pp. 1259-1281.

[9] Cooper T., Hart K., Baldock D. Provision of public goods through agriculture in the European Union. London: Institute for European Environmental Policy, 2009. 396 p.

[10] Sepp, K., Landscape Functions and Ecosystem Services, Rural development and land use, vol. 3, 2012, pp. 39-51.

[11]Tieskens K. F., Schulp C. J., Levers C., Lieskovsky J., Kuemmerle T. et al. Characterizing European cultural landscapes: Accounting for structure, management intensity and value of agricultural and forest landscapes. Land Use Policy, vol. 62, 2017, pp. 29-39.

[12] Science for Environment Policy. Agri-environmental schemes: how to enhance the agricultureenvironment relationship. Bristol: Science Communication Unit, UWE, 2017. 44 p.

[13]EC. Regulation (EU) No 1305/2013 of the European Parliament and of the Council of 17 December 2013 on support for rural development by the European Agricultural Fund for Rural Development (EAFRD) and repealing Council Regulation (EC) No 1698/2005. OJ, L, 347, 2013, pp. 487-548.

[14] Eurostat. Database. [online] [08.01.2018]. Available at: http://ec.europa.eu/eurostat/data/database

[15] Central Statistical Bureau of Latvia (CSB). Database. [online] [11.02.2018]. Available at: http://www.csb.gov.lv/en/dati/

[16] De Groot R., Brander L., Van Der Ploeg S., Costanza R., Bernard F. et al. Global estimates of the value of ecosystems and their services in monetary units. Ecosystem services, vol. 1(1), 2012, pp. $50-61$.

[17] Brouwer R., Brander L., Kuik O., Papyrakis E., Bateman I. A synthesis of approaches to assess and value ecosystem services in the EU in the context of TEEB. Amsterdam: VU University, 2013. $144 \mathrm{p}$.

[18] Franks J. R., Emery S. B. Incentivising collaborative conservation: Lessons from existing environmental Stewardship Scheme options. Land Use Policy, vol. 30(1), 2013, pp. 847-862.

[19]Eurostat. Agri-environmental indicators. [online] [08.01.2018]. Available at: http://ec.europa.eu/eurostat

[20] Pacini G. C., Merante P., Lazzerini G., Van Passel S. Increasing the cost-effectiveness of EU agrienvironment policy measures through evaluation of farm and field-level environmental and economic performance. Agricultural systems, vol. 136, 2015, pp. 70-78.

[21] Melece L., Lakovskis P. Eco-system services and social innovations in rural areas. International Multidisciplinary Scientific GeoConference Surveying Geology and Mining Ecology Management, SGEM, 17(51), 2017, pp. 305-312.

[22]EC (2011). CAP Towards 2020 Impact Assessment: Greening - Results of Partial Analysis on Impact on Farm Income Using FADN. [online] [07.12.2017]. Available at: http://ec.europa.eu/agriculture/rica/pdf/PO0201_greening.pdf

[23] Solazzo A., Jones A., Cooper N. Revising payment for ecosystem services in the light of stewardship: The need for a legal framework. Sustainability, vol. 7(11), 2015, pp. 15449-15463.

[24]EC. Review of greening after one year. SWD(2016) 218 final. [online] [07.12.2017]. Available at: https://ec.europa.eu/agriculture/direct-support/greening_en

[25]Louhichi K., Ciaian P., Espinosa M., Perni A., Gomez y Paloma S. Economic impacts of CAP greening: application of an EU-wide individual farm model for CAP analysis (IFM-CAP). European Review of Agricultural Economics, 2017, pp. 1-34. 